\title{
Role of Accounting Conservatism on the Quality of Financial Statements
}

\author{
Hamidreza Kordlouie ${ }^{1}$, Faramarz Mohammadi ${ }^{1}$, Nader Naghshineh ${ }^{1} \&$ Mehdi Tozandejani ${ }^{2}$ \\ ${ }^{1}$ Faculty of Business and Accounting, Islamic Azad University, EIslamshahr Branch, Tehran, Iran \\ ${ }^{2}$ Faculty of Business and Accounting, International Branch of Islamic Azad University, Qeshm, Iran \\ Correspondence: Hamidreza Kordlouie, Faculty of Business and Accounting, Islamic Azad University, \\ EIslamshahr Branch, Tehran, Iran. Tel: 98-912-513-2200. E-mail: hamidreza.kordlouie@gmail.com
}

Received: October 21, 2013

Accepted: November 14, 2013

Online Published: December 18, 2013

doi:10.5539/ijbm.v9n1p129

URL: http://dx.doi.org/10.5539/ijbm.v9n1p129

\begin{abstract}
This study is an attempt at investigating the relationship between accounting conservatism and the quality of financial statements of the companies accepted in Tehran Stock Exchange (TSE) market. Accounting conservatism is measured through GULIHINE model, while BIDEL, HILLARY, AND VERDI's (2008) model is used for assessing the financial statement quality. Through an experimental method, this study presents the consumers of the accounting information -including market analysts, brokers, managers, and etc- the important effect of accounting conservatism on the financial statements of the companies.

Using the financial statement of 102 companies accepted in TSE market in a period of time, between 2006 and 2010 , it was apparent that there is a significantly positive relationship between accounting conservatism and the quality of financial reports.
\end{abstract}

Keywords: the quality of financial statement reporting, accounting conservatism, fund, investment cash flow, liability items, and debt ratio

\section{Introduction}

As a major feature of financial statement reporting, conservatism is a limiting principle of accounting that plays the key role of confining the optimistic behaviors of the managers as the ones who provide the information, on the one hand, and providing an estimation of the minimal earnings of shareholders and creditors as the major consumers of the information, on the other. Financial statement reporting as well as the accounting system play critical roles in the finance market. Investors and consumers predict the future performance of a given company as a means to assign values to these companies.

Feltham \& Ohlson (1995) introduced conservatism as one of the key factors in reporting operational assets. Some scholars have also studied the effect of conservatism on company's value. Givoly, Hayn (2000) showed that detecting loss would normally happen earlier than detecting profit as the amount of unconditional conservatism increases.

This study aims at finding the relationship between accounting conservatism and the quality of financial reporting in a five-year interval. Through an experimental method, this study presents the consumers of the accounting information-including market analysts, brokers, managers, and etc-the important effect of accounting conservatism on the financial statements of the companies.

\subsection{Theoretical Bases}

Accounting information and financial reporting Management accounting information is usually used by the insiders, namely the staff and management of business firms. This information can also be provided for such outsiders as shareholders, banks, other creditors, and state organizations.

The shareholders who supply the company capital might be interested in knowing the company situation and its performance. In case they decide to sell their shares, they need to know the real value of their shares, based on the information from the financial accounting reports. Meanwhile, if a given company decides to get a loan, the bank or the other creditors should be able to evaluate the economic stature of the company. The part of accounting that deals with processing and presenting the financial information reporting in the way to meet the 
needs and requirements of the outsiders for their decisions is commonly referred to as financial accounting and reporting (Zahedi, 2007).

\subsection{Majors Goals of Financial Reporting}

The main goal of financial reporting is depicting economic occurrences effective on the situation and performance of the business firms for the sake of outsider consumers in the way to help them make economic decisions. This information would normally be presented to the aforementioned parties in the form of financial statements which are the final products of the accounting procedure and financial reporting. The agreed-upon principles of accounting dictate the production of three types of reports: balance sheet, statement of loss and gain, and cash flow statement.

The major goals of financial and accounting reporting, for the outsiders, include:

1) Financial reporters are to provide the information that could aid the current and prospective decision makers and creditors in making financial decisions in an effective way.

2) Financial reporting is expected to provide investors, creditors, and others with evaluations as well as timings on the expected returns of firms. An investors and creditors' expectation of business firms is significantly under the effect of future liquidity prospect of these firms.

3) Financial reporting is also expected to provide information on the economic resources of business firms as well as the resulting liabilities in return for the aforementioned resources.

4) Finally, financial reporting is expected to reflect the financial achievements of business firms in any given financial cycle (Alivar, 2001).

Goal (1) entails all of the accounting information; nonetheless, the other goals represent various types of financial statements. In this way, goal (2) is a reflection of the expectations towards operational cash flow. By the same token, goal (3) relates to the balance sheet, while goal (4) is about the statement of loss and gain.

In order to fulfill accounting goals, an abundance of data is to be provided regarding a firm. This would end up in production of various types of financial statements. In other words, the goals of financial reporting necessitate the presentation of separate statements which are basically related. Each and every one of these basic financial reports play a role in the fulfillment of the purposes defined for financial reporting. Furthermore, the role of the sections of these reports is to be acknowledged in the way of fulfilling these goals.

\subsection{A Definition for Conservatism}

One of the off-shoots of an asymmetric conservative behavior on profits and losses is reporting less than true net value of assets. Legislators of financial markets, establishers of standards as well as academicians criticize conservatism on the grounds that its depiction of 'less than true' in the present cycle could lead to 'less than true' reports on the future costs in a way that the profits in the future cycles will have been depicted as 'more than true'. Nonetheless, Accounting Principles Board (APB), in its 4th opinion lists conservatism a covenant to modify financial accounting. It further states that the assets and debts are normally evaluated under unclear circumstances; therefore, the accountants would be drawn to reply cautiously.

Field tracks conservatism back to middle ages when owners of huge assets would abdicate their errands to overseers. Soon, these overseers found out that conservatism could be a means to protect themselves. Not predicting the increase in the asset values when uncalled for events could cause the decrease in the asset value was a strategy employed by the overseers to evade owners' accusation of the overseers for the loss (Kisou, Vigant, \& Warfield, 2001). "Traditionally, conservatism in accounting is a means to the end of minimizing unwanted consequences in the time of uncertainty for choosing a method that could lead to an overestimation of assets". Article 95 of APB's 2nd opinion (1980) states that, "in case there are two estimations of equal probability for any given receivable or prestable, conservatism would choose the one with the least optimism included".

According to Beaver (1988), conservative behavior is in the way that could lead to choosing smaller incomes (as opposed to bigger incomes) and bigger costs (as opposed to smaller costs) when reporting. In addition, this method dictates the choice of losses not gained while undermining the profits not made. In this way, as stated by Feltham \& Ohelson (1995), it is expected that this method of financial reporting lead to a difference between the sale value and net book value of the stocks in the long run (Shroff, Venkataraman \& Zhang, 2004).

The principles of the minimum flat cost, market for inventory valuation, detecting losses inflicted as a result of capital loss for long term asset, and accounting probable losses and probable profits are all samples of conservative accounting routines that can help detection of bad news at an earlier-and more appropriate - time. 
With an eye on the principle of conservatism, accounting routines have a tendency to impose uncertainty and necessitate stricter validation criteria in reporting profit when it comes to face ambiguities on the way to successfully report a financial occurrence. (Shroff, Venkataraman \& Zhang, 2004)

As accounting profit provides information on the current and future flow of the cash in a company, directly connects to the stock price; therefore, it can affect the market value of the company (Watts \& Zimmerman). With respect to market response towards the reported profits, the effeiceint market theory shows that systematically, different methods of the Generally Accepted Accounting Principles (GAAP) could not mislead investors in calculating reported operational profits (ibid). In this way, based on the theoretical discussions proposed by Hendrickson \& Van Breada (1992), investors are to employ a degree of conservatism in their expectations of the application of accounting profit for estimating the future cash flow (Scott, 2004). From the perspective of those who report financial statements, conservatism is considered to be a method that could lead to one of the following consequences:

1) Later detection of sales revenues;

2) Earlier detection of costs;

3) Under-estimation of assets;

4) Over-estimation of debts (Shabahand, 2003).

\subsection{The Stature of Conservatism in Accounting Standards}

As with article 2-18 of the theoretical concepts of financial reporting of Iranian standards, the word 'conservatism' is considered to be a quality of the accounting information that makes the financial statements useful for its consumers. In addition, when it comes to gearing costs and income, there is a condition that makes interpreting this article problematic:

The technical committee of the Iranian organization for auditing recognizes the term caution in place of conservatism in its theoretical concepts of financial reporting. It is due to the fact that its theoretical concepts have been borrowed from the Association of Certified Acountants (ACCA) where caution is replaced for conservatism, as a feature of dependability of the report.

\subsection{The Quality of Financial Reporting}

Following Vordy (2006), and Bidel, Hillary, \& Vordi (2008), the reporting quality is the capability of financial statements in conveying company's operation information and especially predicting the cash flow. As stated in article 1-5 of the theoretical concepts of financial reporting standards of Iran, making economic decision by the users of financial statements. At the end of the day, this power determines the capacities of the business firm for producing cash and the probability of this production. This power, also, is a reflection of the firm's potentials to make various types of payments such as paying staff, paying the suppliers of goods and services, managing financial expenses, investments, paying off the loans, and distribution of profit among investors. Evaluating the ability to produce cash for the purpose of predicting expected cash flow and financial flexibility can be facilitated through focusing on financial status, financial performance, and cash flows of the given business firm.

\section{Literature Review}

Nahandi, Hasanzadeh \& Mahmudzadeh (2011) found out the relationship between some of the mechanisms of the strategies of the firms as well as conservatism on financial reporting. Conservatism has the potential to usefully affect the strategies of the firms. On the one hand, it reduces the chance for opportunistic payments to the managers. On the other hand, it forces the management to report the losses sustained from selling out assets as well as halting operations. Finally, conservatism makes managers avoid the continuation of investments on projects with negative current net value. Conservatism could reduce the level of investment, and conflicts of interest between management and outside shareholders and agency costs is limited.

This paper employs the two models of Basso (1997) and Rechodari \& Watz (2006) to asses conservatism. In addition, the ownership of organizational shareholders, ownership concentration, and the independence of the members of the board of directors were all considered as mechanisms at the service of the firms' strategies. The statistical universe of this study consisted of the companies accepted in Tehran Stock Exchange (TSE). Through the elimination method of sampling, 60 firms within a period of time from 2001 to 2008 were chosen as the subjects of the study. Through multivariate regression, the results yielded no significant relationship between the strategic mechanisms and conservatism in financial reporting. It should be mentioned that this study included some moderating variables, too. 
Ashton and Wang (2010) found that Left-Over income is the result of a crucial theoretical connection between stock evaluation and financial variables. While it was developed by various researchers, they unanimously agree on the fact that the how-being of policy effect accounting within the model structure provides the experimental support for this model. The best attitude for this model is weak and contradictory at its best. As a matter of fact, this model is used to detect the interdependence between evaluation parameters of its and the dynamicity structure of the income information and accounting conservatism.

Biddle, Ma \& Song (2010) suggested that there is a negative relationship between unconditioned conservatism and risk of bankruptcy. In addition, the relationship between conditioned conservatism and risk of bankruptcy is also a negative one. These findings could lead to consideration of a behavioral role for conservatism at the service of facing the commitments of the company.

Sung Wang (2011) in an article about the role of conservatism in managerial accounting and controlling creditors, stated that breaking the promise by shareholders/managers for the cession of rights to the creditors, as well as the need to develop a clear mechanism for the creditors to impose their priorities on financial reporting of the firms makes creditors request the employment of accounting conservatism in the wake of breaking the promises.

Han (2012). The role of conservatism in accounting, final ownership, and investment on improving the productivity of firms:

This article is an attempt at studying the effect of conservatism on the behavior of firms and investment in China. When there is a positive relationship between accounting conservatism and financial expenditures, conservatism can increase the level of investment through reducing information on skewness and financing costs. Meanwhile, when there is a significantly negative relationship between accounting conservatism and financing costs, and there is enough finance used for financing within the firm, conservatism could decrease the level of investment, leading to a decreased clash on interest between management and shareholders as well as a decrease on the costs of representation.

\section{Research Hypotheses and Results}

Hypothesis 1: there is relationship between accounting conservatism and financial report quality in the finance markets of Iran.

Hypothesis 2: there is relationship between accounting conservatism and liabalities in the finance markets of Iran.

Hypothesis 3: there is relationship between accounting conservatism and the funds kept in the finance markets of Iran.

Hypothesis 4: there is relationship between accounting conservatism and fluctuations in the debts of firms within the finance markets of Iran.

Hypothesis 5: there is relationship between accounting conservatism and cash resulting from investment in the finance markets of Iran.

Following, a brief report on the results of analyses for each hypothesis will be provided.

\subsection{Results of Hypothesis 1}

Below is the statistical table for the results of hypothesis number one testing:

Table 1. Pearson correlation

\begin{tabular}{cccc}
\hline & Conserv. & FQ.t & \\
\hline Financial reporting quality & $0.405^{* *}$ & 1 & Pearson correlation \\
& 0.000 & & sig.(2-tailed) \\
& 510 & 510 & Number \\
Conservatism & 1 & $0.405^{* *}$ & Pearson correlation \\
& 510 & 0.000 & sig.(2-tailed) \\
& & 510 & Number \\
\hline
\end{tabular}

**. Correlation is significant at the 0.01 level (2-tailed). 
As shown in table 1, the Pearson correlation coefficient for the variables of 'quality of reporting and conservatism' has been calculated for the whole model. The level of significance has been 0.01 . the numbers with an asterisk are significantly meaningful at $99 \%$. For example, the variables of quality of financial reporting and conservatism have a positive correlation at 0.405 , i.e., there is a direct relationship between conservatism and the quality of financial reporting in a way that more conservative companies have a higher reporting quality.

\subsection{Results of Hypothesis 2}

Results of testing of the second hypothesis are shown as follows:

Table 2. Pearson correlation

\begin{tabular}{lccc}
\hline & & Conserv. & ACCROUAL \\
\hline \multirow{2}{*}{ Conservatism } & Pearson corrlelation & 1 & $-0.196^{* *}$ \\
& sig.(2-tailed) & & 0.000 \\
& No. & 510 & 510 \\
\multirow{2}{*}{ Liabilities } & Pearson Correlation & $-0.196^{* *}$ & 1 \\
& sig.(2-tailed) & 0.000 & \\
& No. & 510 & 510 \\
\hline
\end{tabular}

**. Correlation is significant at the 0.01 level (2-tailed).

As shown in Table 2, the Pearson correlation coefficient for the variables of 'accounting conservatism and non-operational Liabilities' has been calculated for the whole model. The level of significance has been 0.01 . The numbers with an asterisk are significantly meaningful at $99 \%$. For example, the variables of non-operational liabilities and conservatism have a negative correlation at $-0.196^{* *}$, i.e., there is a negative relationship between conservatism and the non-operational liabilities in a way that imbalance in implementing conservatism to profits and losses could lead to imbalance of liabilities. Losses would be perfectly identified, while profits are accrued. This could lead to a reduction of liabilities to a minus; therefore, non-operational liabilities are reported less than the true value of theirs, whereas the total non-operational liabilities in the course of time will depict negative stow due to their totally different patterns. (13/1) (VIII/1).

\subsection{Results of Hypothesis 3}

Results of testing of the third hypothesis are shown as follows:

Table 3. Correlation coefficient, coefficient of determination, modified coefficient of determination, and DORBIN \& WATSON test for accounting conservatism and funds there is relationship between accounting conservatism and fluctuations in the debts of firms within the finance markets of Iran

\begin{tabular}{|c|c|c|c|c|}
\hline \multicolumn{5}{|c|}{$\begin{array}{l}\mathrm{ACC}_{\text {it }}=\mathrm{NI}_{\text {it }}+\mathrm{DEP}_{\text {it }}-\mathrm{Cfo}_{\text {it }} \\
\mathrm{oACC}=\Delta \mathrm{AR}_{\text {it }}+\Delta \mathrm{I}_{\mathrm{a}}+\Delta \mathrm{PE}_{\mathrm{it}}-\Delta \mathrm{AP}_{\text {it }}-\Delta \mathrm{TP}_{\text {it }} \\
\mathrm{NoACC}_{\text {it }}=\mathrm{ACC}_{\text {it }}-\mathrm{oACC}_{\text {it }}\end{array}$} \\
\hline Model & $\begin{array}{l}\text { Standard error of } \\
\text { estimation }\end{array}$ & $\begin{array}{c}\text { Modified determination } \\
\text { coefficient }\end{array}$ & Correlation coefficient & $\begin{array}{l}\text { DORBIN } \\
\text { WATSON }\end{array}$ \\
\hline 1 & 1.00917 & 0.011 & 0.145 & 2.006 \\
\hline
\end{tabular}

a. Predictors: Constant, FA.t, F.CFO, AS.t, P.CFO, CFO

b. Dependent Variable: NO.ACC

According to Table 1, one of the presuppositions for regression is the independence of errors. If this presupposition is rejected, and it is concluded that the errors are correlated, regression test cannot be employed. DORBIN-WATSON statistic is therefore used to study the independence of errors. If the correlation between the errors is in between 1.5 to 2.5 , then the correlation of the errors would be rejected, and we can employ regression. According to table 3, the amount is 2.006 which signify the independence of the errors. Therefore, there is no correlation between the errors, and regression can be employed. 
Table 4. Anova for conservatism and liabilities

\begin{tabular}{lcccccc}
\hline \multicolumn{1}{c}{ Model } & $\begin{array}{c}\text { Level of } \\
\text { meaningfulness }\end{array}$ & F statistic & $\begin{array}{c}\text { Mean } \\
\text { Square }\end{array}$ & df & $\begin{array}{c}\text { Sum of } \\
\text { Squares }\end{array}$ & Conclusion \\
\hline Regression & 0.059 & 2.147 & 2.187 & 5 & 10.935 & Hypo. Rejected \\
Residual & & 1.018 & 503 & 512.263 & \\
Total & & & 508 & 523.198 & \\
\hline
\end{tabular}

a. Predictors: Constant, FA.t, F.CFO, AS.t, P.CFO, CFO.

b. Dependent Variable: NO.ACC.

According to table 4 , the general meaningfulness of the regression model can be concluded based on the following statistical defaults:

As the level of significance is above 5\%, the linear relationship between the two variables cannot be confirmed. We study the type of the relationship between the variables in what follows:

Table 5. Coefficients of regression equation

\begin{tabular}{ccccccc}
\hline & & & Standardized & \multicolumn{2}{c}{$\begin{array}{c}\text { Un-standardized } \\
\text { coefficient }\end{array}$} & Conclusion \\
\cline { 3 - 5 } Model & $\begin{array}{c}\text { Level of } \\
\text { meaningfulness }\end{array}$ & $\mathrm{T}$ & Beta & $\begin{array}{c}\text { Std. } \\
\text { Error }\end{array}$ & $\mathrm{B}$ & \\
\hline $\begin{array}{c}\text { Constant } \\
\text { P.CFO }\end{array}$ & 0.377 & -.883 & & 0.079 & -0.070 & Rejected \\
$\begin{array}{c}\text { Operational cash } \\
\text { flow }\end{array}$ & 0.313 & 1.010 & 0.045 & 0.000 & 0.000 & Confirmed \\
$\begin{array}{c}\text { F.CFO } \\
\begin{array}{c}\text { Permanent } \\
\text { physical asset }\end{array}\end{array}$ & 0.006 & 2.779 & 0.127 & 0.000 & 0.001 & Rejected \\
Sales income & 0.625 & 0.489 & 0.022 & 0.000 & 0.000 & Rejected \\
\hline
\end{tabular}

a. Dependent Variable: NO.ACC.

The output of table 5, a fixed amount and a variable coefficient for the regression equation has been concluded. The equation is as follows:

$$
R E T=-0.070+.001 \beta_{\text {CON }}+e_{i}
$$

According to the output of table 5, the other columns of the table include the B column coefficient, $t$ value, and significance value - this is considered 0 in column B for the purpose of equality hypothesis testing.

As can be seen in the output, the regression coefficient equality and the fixed amount are below $5 \%$, these two coefficients do not equal zero. In this way, they cannot be omitted from regression equation.

\subsection{Results of Hypothesis 4}

There is relationship between accounting conservatism and fluctuations in the debts of firms within the finance markets of Iran. 
Table 6. Correlation coefficient, coefficient of determination, modified coefficient of determination, and DORBIN \& WATSON test for accounting conservatism and funds.

\begin{tabular}{ccccc}
\hline & CASH $_{t}=\alpha+\beta$ CONSV $_{t+1}+\sum Y$ CONTROLS $_{t}+\varepsilon_{t}$ & $(2)$ \\
\hline Model & $\begin{array}{c}\text { Standard error of } \\
\text { estimation }\end{array}$ & $\begin{array}{c}\text { Modified } \\
\text { determination } \\
\text { coefficient }\end{array}$ & Correlation coefficient & $\begin{array}{c}\text { DORBIN \& } \\
\text { WATSON }\end{array}$ \\
\hline 1 & 1.01146 & 0.021 & 0.158 & 1.702 \\
\hline
\end{tabular}

a. Predictors: (Constant), J.CONTROLS, CONSERV.

b. Dependent Variable: NORMAL.CASH.t

As shown in Table 6, the errors are independent, and there is no correlation between them. If the correlation between the errors is in between 1.5 to 2.5 , then the correlation of the errors would be rejected, and we can employ regression. According to table 6 , the amount is 1.702 which signifies the independence of the errors. Therefore, there is no correlation between the errors, and regression can be employed.

Table 7. ANOVA for the variables of conservatism and funds

\begin{tabular}{lcccccc}
\hline \multicolumn{1}{c}{ Model } & Level of meaningfulness & F & Mean Square & df & $\begin{array}{c}\text { Sum of } \\
\text { Squares }\end{array}$ & Result \\
\hline $\begin{array}{l}\text { Regression } \\
\text { Residual }\end{array}$ & 0.000 & 6.800 & 6.615 & 2 & 13.231 & Confirmed \\
total & & & 1.023 & 507 & 518.685 \\
\hline
\end{tabular}

a. Predictors: (Constant), J.CONTROLS, CONSERV.

b. Dependent Variable: NORMAL.CASH.t.

As can be seen in Table 7, the overall meaningfulness of regression model is tested through ANOVA. As the level of significance is below $5 \%$, the linear relationship between the two variables is confirmed. Now, it is time to look for the relationship.

Table 8. Regression coefficients for conservatism and funds

\begin{tabular}{|c|c|c|c|c|c|c|}
\hline \multirow{2}{*}{ Model } & \multirow{2}{*}{ Level of meaningfulness } & \multirow{2}{*}{$\mathbf{t}$} & \multirow{2}{*}{$\begin{array}{c}\text { Standardized coefficient } \\
\text { Beta }\end{array}$} & \multicolumn{2}{|c|}{ Non-standardized coefficient } & \multirow{2}{*}{ Result } \\
\hline & & & & Std. Error & B & \\
\hline (Constant) & 0.532 & -0.625 & & 0.460 & -0.029 & \\
\hline Consev. & 0.001 & 3.365 & 0.148 & 0.000 & 1.096 & Meaningful \\
\hline J.CONTROLS & 0.147 & -1.454 & -0.064 & 0.002 & -0.002 & Not Meaningful \\
\hline
\end{tabular}

a. Dependent Variable: NORMAL.CASH.t.

In the B column, the fixed amount and the variable coefficient are presented respectively. The equation for them is as follows:

$$
Y=-0.029+1.096 X
$$

In table 8 , the other columns include column $B$ coefficient amounts, $t$ value, and the level of significance. The level of significance is considered zero for hypothesis testing of each of the coefficients in column $\mathrm{B}$. as the statistic is significant at $<0.05$, the regression coefficient, is than 0.05 . In this way, the assumption that these two coefficients do not equal zero is rejected, and they should be included in the regression equation. 


\subsection{Results of Hypothesis 5}

Table 9. The correlation coefficient, determination coefficient, the modified determination coefficient, and the DORBIN-WATSON test for conservatism and debt ratio

\begin{tabular}{|c|c|c|c|c|}
\hline \multicolumn{4}{|c|}{$\operatorname{pr}\left(\operatorname{DISSUE}_{t}\right)=\alpha+\beta \operatorname{CONSV}_{t+1}+\Psi\left(\operatorname{LEVERAGE}_{t}+\operatorname{LEVERAGE}_{t+1}\right)+\sum Y \operatorname{CONTROLS}_{t}+\varepsilon_{t}$} & \multirow[b]{2}{*}{$\begin{array}{l}\text { DORBIN } \\
\text { WATSON }\end{array}$} \\
\hline Model & $\begin{array}{l}\text { Standard error of } \\
\text { estimation }\end{array}$ & $\begin{array}{c}\text { Modified determination } \\
\text { coefficient }\end{array}$ & Correlation coefficient & \\
\hline 1 & 0.37611 & 0.029 & 0.185 & 1.521 \\
\hline
\end{tabular}

a. Predictors: Constant, LEV.F.LEV, J.CONTROLS, CONSERV.

b. Dependent Variable: pr.DISSUE.t.

According to table 9, the independence of the errors is obvious. This indicates non-correlation between the errors. DORBIN-WATSON statistic is therefore used to study the independence of errors. If the correlation between the errors is in between 1.5 to 2.5, then the correlation of the errors would be rejected, and we can employ regression. According to table 9 , the amount is 2.006 which signify the independence of the errors. Therefore, there is no correlation between the errors, and regression can be employed.

Table 10. Anova for conservatism and debt ratio

\begin{tabular}{ccccccc}
\hline Model & $\begin{array}{c}\text { Level of } \\
\text { meaningfulness }\end{array}$ & F & Mean Square & $\begin{array}{c}\text { Degree of } \\
\text { freedom }\end{array}$ & Sum of Squares & Results \\
\hline Regression & 0.000 & 3.876 & 0.847 & 3 & 2.54 & Accepted \\
Residual & & & 0.141 & 506 & 71.578 & \\
Total & & & 509 & 74.118 & \\
\hline
\end{tabular}

a. Predictors: Constant, LEV.F.LEV, J.CONTROLS, CONSERV.

b. Dependent Variable: pr.DISSUE.t.

Table 11. Indicates the regression analysis for conservatism and debt ration

\begin{tabular}{|c|c|c|c|c|c|c|}
\hline \multirow{2}{*}{ Model } & \multirow{2}{*}{$\begin{array}{c}\text { Level of } \\
\text { meaningfulness }\end{array}$} & \multirow{2}{*}{$\mathbf{t}$} & \multirow{2}{*}{$\begin{array}{c}\text { Standardized coefficient } \\
\text { Beta }\end{array}$} & \multicolumn{2}{|c|}{$\begin{array}{c}\text { Un-standardized } \\
\text { coefficient }\end{array}$} & \multirow{2}{*}{ Results } \\
\hline & & & & $\begin{array}{c}\text { Std. } \\
\text { Error }\end{array}$ & B & \\
\hline Constant & 0.000 & 8.527 & & 0.023 & 0.192 & \\
\hline Conserv. & 0.009 & 2.622 & 0.115 & 0.000 & 3.185 & Confirmed \\
\hline J.CONTROLS & 0.001 & -3.349 & -0.147 & 0.001 & -0.002 & Confirmed \\
\hline LEV.F.LEV & 0.500 & -0.675 & -0.030 & 0.000 & -3.742 & Rejected \\
\hline
\end{tabular}

a. Dependent Variable: pr.DISSUE.t.

According to table 11, the overall meaningfulness of regression model is tested through ANOVA. As the significance level is less than 0.05 , the linear relationship between the two variables is confirmed. It is time to look for the relationship.

In column $\mathrm{B}$, as can be seen, the fixed amount and the independent variable coefficient for the regression equation is presented. The equation also is as follows:

$$
Y=0.192+3.185 X
$$




$$
Y=0.192+(-0.002) X
$$

As can be seen, the other columns in the table include column B coefficient amounts, $t$ value, and the level of significance. The level of significance is considered zero for hypothesis testing of each of the coefficients in column B. as the statistic is significant at $<0.05$, the regression coefficient, is smaller than 0.05 . In this way, the assumption that these two coefficients do not equal zero is rejected, and they should be included in the regression equation.

\subsection{Results of Hypothesis 6}

Table 12. the correlation coefficient, determination coefficient, the modified determination coefficient, and the DORBIN-WATSON test for conservatism and cash resulting from finance

$$
\text { CFSI }_{t}=\alpha+\beta \text { CONSV }_{t+1}+\sum Y \operatorname{CONTROLS}_{t}+\varepsilon_{t}
$$

\begin{tabular}{cccc}
\hline Model & $\begin{array}{c}\text { Standard error of } \\
\text { estimation }\end{array}$ & $\begin{array}{c}\text { Modified determination } \\
\text { coefficient }\end{array}$ & Correlation coefficient \\
\hline 1 & 2.00539 & 0.010 & 0.117 \\
\hline
\end{tabular}

a. Predictors: Constant, J.CONTROLS, CONSERV.

b. Dependent Variable: CFSI.t.

According to table 12, the independence of the errors is obvious. This indicates non-correlation between the errors. DORBIN-WATSON statistic is therefore used to study the independence of errors. If the correlation between the errors is in between 1.5 to 2.5 , then the correlation of the errors would be rejected, and we can employ regression. According to table 12, the amount is 1.939 which signify the independence of the errors. Therefore, there is no correlation between the errors, and regression can be employed.

\begin{tabular}{|c|c|c|c|c|c|c|}
\hline Model & $\begin{array}{c}\text { Level of } \\
\text { meaninfulness }\end{array}$ & $\mathbf{F}$ & Mean Square & Df & Sum of Squares & Results \\
\hline Regression & 0.031 & 3.492 & 14.043 & 2 & 28.085 & Confirmed \\
\hline Residual & & & 4.022 & 507 & 2038.951 & \\
\hline Total & & & & 509 & 2067.036 & \\
\hline
\end{tabular}

Table 13. Anova for conservatism and cash resulting from finance

a. Predictors: Constant, J.CONTROLS, CONSERV.

b. Dependent Variable: CFSI.t.

Table 13 indicates the regression analysis for conservatism and cash from financing. According to this table, the overall meaningfulness of regression model is tested through ANOVA. As the significance level is less than 0.05 , the linear relationship between the two variables is confirmed. It is time to look for the relationship. 
Table 14. Indicates the regression analysis for conservatism and cash flow from investments

\begin{tabular}{|c|c|c|c|c|c|c|}
\hline \multirow[t]{2}{*}{ Model } & \multirow{2}{*}{$\begin{array}{c}\text { Level of } \\
\text { meaningfulness }\end{array}$} & \multirow[t]{2}{*}{$\mathbf{T}$} & \multirow{2}{*}{$\begin{array}{c}\text { Standardized } \\
\text { coefficient } \\
\text { Beta } \\
\end{array}$} & \multicolumn{2}{|c|}{$\begin{array}{c}\text { Non-standardized } \\
\text { coefficient }\end{array}$} & \multirow[t]{2}{*}{ Result } \\
\hline & & & & Std. Error & B & \\
\hline Constant & 0.000 & 35.517 & & 0.091 & 3.250 & \\
\hline Conserv. & 0.013 & 2.484 & 0.110 & 0.000 & 1.604 & Confirmed \\
\hline J.CONTROLS & 0.299 & -1.039 & -0.046 & 0.003 & -0.003 & Rejected \\
\hline
\end{tabular}

a. Dependent Variable: CFSI.t.

In column $\mathrm{B}$, as can be seen, the fixed amount and the independent variable coefficient for the regression equation is presented. The equation also is as follows:

$$
Y=3.250+1.604 X
$$

As can be seen, the other columns in the table include column B coefficient amounts, $t$ value, and the level of significance. The level of significance is considered zero for hypothesis testing of each of the coefficients in column $\mathrm{B}$. as the statistic is significant at $<0.05$, the regression coefficient, is smaller than 0.05 . In this way, the assumption that these two coefficients do not equal zero is rejected, and they should be included in the regression equation.

\section{Conclusion}

The goal of this study was to compare various models of presentation with model of conservatism in the way to achieve the best and most precise model for predicting the relationship between conservatism and the quality of financial reports. In so doing, some tests were devised. In a new move, accounting items were used in this study in order to determine the most suitable model for conservatism (GIIULI HINE) and quality of financial reporting (BIDEL, HILLARY, \& VORDI, 2008) were employed on the companies accepted in TSE market. The analysis of the statistical results indicates that there is a meaningful relationship between conservatism and the quality of financial reporting. The companies seeking development, need to improve the quality of their reporting in order for their customers and counterparts to predict the future course of cash flow in the company. In this way, the counterparts and the customers can maintain business relations, being confident of the financial stature of the company.

This study was also a chance to scrutinize the relationship between conservatism with liabilities. It was concluded that the companies that focus on conservatism would end up with a reduce non-operational liabilities. Based on the research hypotheses, it was predicted that with the increase in the funds of a company conservatism would surge. As a result of the statistical operations, it was observed that there is a direct and meaningful relationship between funds and conservatism. Finally, with the 5th and 6th hypotheses confirmed, it was concluded that there is also a meaningful relationship between debt ratio and cash flow resulting from investment with conservatism.

\section{References}

Ahmed, A. S., \& Duellman, S. (2007). Accounting Conservatism and Board of Director Characteristics: an Empirical Analysis. Working paper.

Ashton, D. J., \& Wang, P. (2010). Valuation and Conservatism. Working paper.

Ball, R., \& Shivakumar, L. (2005). Earnings quality in UK prhvate firms: Comparative loss recognition timeliness. Journal of Accounting and Economics, 39, 83-128. http://dx.doi.org/10.1016/j.jacceco.2004.04.001

Banker, R. D., Basu, S., Byzalov, D., \& Chen, Y. J. (2013). Asymmetric Timeliness of Earnings: Conservatism or Sticky Costs. Temple University-Fox School of Business, Philadelphia, United States.

Beaver, W., \& Ryan, S. (2000). Biases and lags in book value and their effects on the ability of the book-to-market ratio to predict book return on equity. Journal of Accounting Research, 38, 127-128. http://dx.doi.org/10.2307/2672925

Beaver, W. H., \& Ryan, S. G. (2005). Conditional and unconditional conservatism: concepts and modeling. Review of Accounting Studies, 10(2-3), 269-309. http://dx.doi.org/10.1007/s11142-005-1532-6 
Biddle, G. C., Ma, M. L., \& Song, F. M. (2010). Accounting Conservatism and Bankruptcy Risk. Faculty of Business and Economics. The University of Hong Kong.

Chung, H. H., \& Wynn, J. P. (2008). Managerial legal liability coverage and earnings conservatism. Journal of Accounting and Economics, 46(1), 135-153. http://dx.doi.org/10.1016/j.jacceco.2008.03.002

Dimitropoulos, P. E., \& Asteriou, D. (2008), Timeliness, conservatism and financial transparent firms under the Greek accounting setting. Review of Accounting and Finance, 7(3), 252-269. http://dx.doi.org/10.1108/14757700810898249

Givoly, D., Hayn, C., \& Natarajan, A. (2007). Measuring Reporting conservatism. The Accounting Review, 82, 65-106. http://dx.doi.org/10.2308/accr.2007.82.1.65

Hendriksen, E. S. (1982). Accounting Theory (4th ed.). Homewood, IL: Richard D Irwin.

LaFond, R., \& Watts, R. (2007). The information role of conservatism. Working paper. Massachusetts Institute of Technology.

LaFond, R., \& Watts, R. (2006). The Information Role of Conservative Financial Statements. Retrieved from http://www.ssrn.com

Lara, J. M. G., Osma, B. G., \& Penalva, F. (2007). Cost of Equity and Accounting Conservatism. Chicago: Annual Conference of the American Accounting Association.

Penman, S. H., \& Zhang, X. J. (2002). Accounting conservatism and the quality of earnings and stock returns. The Accounting Review, 77, 237-264. http://dx.doi.org/10.2308/accr.2002.77.2.237

Roychowdhury, S., \& Watts, R. L. (2007). Asymmetric timeliness of earnings, market to book and conservatism in financial reporting. Journal of Accounting and Economics, 44, 2-31. http://dx.doi.org/10.1016/j.jacceco.2006.12.003

Watts, R. (2003a). Conservatism in accounting Part I: Explanations and implications. Accounting Horizons, 17(3), 207-221. http://dx.doi.org/10.2308/acch.2003.17.3.207

Watts, R. L. (2003b). Conservatism in accounting Part II: evidence and research opportunities. Accounting Horizons, 17(4), 287-301. http://dx.doi.org/10.2308/acch.2003.17.4.287

Zhang, J. (2006). The contracting benefits of accounting conservatism to lenders and borrowers. Working paper. University of Southern California.

\section{Copyrights}

Copyright for this article is retained by the author(s), with first publication rights granted to the journal.

This is an open-access article distributed under the terms and conditions of the Creative Commons Attribution license (http://creativecommons.org/licenses/by/3.0/). 